\title{
The Roosting Ecology OF THE Silver-Haired BAT LASIONYCTERIS NOCTIVAGANS IN THE BLACK Hills OF SOUTH DAKOTA
}

\author{
TODD A. MATTSON $\downarrow$ NANCY L. STANTON \\ STEVEN W. BUSKIRK $\downarrow$ DEPARTMENT OF ZOOLOGY \& PHYSIOLOGY \\ UNIVERSITY OF WYOMING $\downarrow$ LARAMIE
}

\begin{abstract}
The silver-haired bat Lasionycteris noctivagans occurs widely across North America (Kunz 1982a) at highly variable densities (Barbour and Davis 1969). Still, little is known of its ecology and behavior, especially of its summer roosting habits (Kunz 1982a). Summer roost sites have been alledged to be mostly in trees, but few reliable records are available (Kunz 1982a). Barclay et al. (1988) searched trees in Manitoba and found silverhaired bats roosting under folds of loose bark during the migration period. Likewise, Parsons et al. (1986) and Novakowski (1956) each reported finding a small maternity colony of silver-haired bats in hollow trees in Canada.
\end{abstract}

Studies in the northwestern United States have suggested that silver-haired bats occur more frequently in late-successional forest dominated by trees over $200 \mathrm{yr}$ old than in early seres (Perkins and Cross 1988, Thomas 1988). This association has been attributed to the presence of high concentrations of standing dead trees, some of which have exfoliated bark, cracks in the wood, and cavities excavated by birds; sites that may be preferred by bats for roosting (Perkins and Cross 1988, Thomas 1988). To better understand roost selection and habitat requirements of silver-haired bats, we investigated the roosting ecology of this species in the Black Hills of South Dakota.

\section{$\downarrow \quad$ STUdY AREA}

Our study area was located in the southern Black Hills of South Dakota in and around Jewel Cave National Monument. The topography of the area varies from rolling highlands with park-like valleys to narrow, steep canyons with rocky ridge tops. Forests are dominated by pure stands of ponderosa pine Pinus ponderosa.

\section{$\downarrow \quad$ MATERIALS AND METhOdS}

Silver-haired bats were captured using mist nets over water bodies between 25 June and 4 August 1994. We attached 0.7-g radio transmitters (model BD-2B, Holohil Systems Ltd., Woodlawn, Ontario) to four adult males and 12 adult females. We used hand-held, 3-element yagi antennas and portable receivers (model TR-2, Telonics, Mesa, AZ) to track bats to roost trees. If we were unable to determine where in the tree the bat was roosting, or whether it was roosting alone or communally, we returned to the tree before dusk to watch and count bats leaving the site.

Each roost tree was classified as being used by either a maternity aggregation or a solitary bat. Maternity roosts were located by tracking a pregnant 
or lactating female and always contained more than one bat. Solitary roosts contained only a single bat and were located by tracking males or females that did not appear pregnant or lactating or were postlactating.

We identified roost trees to species and measured height and diameter at breast height (dbh). We placed each roost tree into one of seven decay stages; decay stage 1 included live trees with intact bark and branches, whereas decay stage 7 included dead trees that had broken tops, were clean of bark, and were beginning to decompose (Thomas et al. 1979). For purposes of analysis, we combined the number of roosts into three tree decay stage categories; stage 1-3, stage 4, and stage 5-7.

\section{RESULTS}

On average, we were able to track transmittered bats for eight days (range: 1 - 20). We located 39 roosts used by silver-haired bats, all of which were in different trees. We followed all 16 transmittered bats to at least one roost tree. Ten trees were used by maternity aggregations averaging $22.2 \pm 4.9$ adults and juveniles (range: $6-55$ ).

Because we made no effort to capture bats at the roosts, we are unsure of the ratio of adults to juveniles. None of the four adult males was ever tracked to a maternity aggregation. Maternity roosts were found exclusively in tree cavities, primarily those created by woodpeckers (Picidae). We found solitary bats roosting under loose bark $(\underline{n}=15)$, in a tree crack or crevice $(\underline{n}=5)$, or a woodpecker cavity $(\underline{n}=1)$. We were unable to determine specifically where a bat was roosting in eight trees. The height of maternity roosts averaged $10.2 \pm 1.5 \mathrm{~m}$ (range: 3.1 - 13.8). The height of solitary roosts that we were able to measure, averaged $3.4 \pm 0.5 \mathrm{~m}$ (range: 0.9-8.9). Both maternity aggregations and solitary bats selected sites that had cavity openings or roosts on the south facing sides of tree boles over other aspects $\left(X^{2}=15.8\right.$, d.f. $\left.=3, P=0.0012\right)$.

Of the 39 roost trees, 38 were ponderosa pine and one was an aspen. Of 508 trees on the neighborhood plots, $95 \%$ were ponderosa pine and $5 \%$ were other species, including aspen, juniper, and paper birch. The ten trees used by maternity aggregations of silver-haired bats ranged from decay stage 2 to 7 (median $=5$ ). The 29 trees used by solitary bats varied from tree decay stage 3 to 7 (median $=4)$. Trees in the neighborhood plots ranged from decay stage 1 to 7 (median $=1$ ). Bats in maternity aggregations selected roost trees in significantly different decay stages than solitary roosting bats $\left(\mathrm{X}^{2}=10.2\right.$, d.f. $\left.=2, \underline{\mathrm{P}}=0.0062\right)$. Roost trees averaged $14.2 \pm 0.9 \mathrm{~m}$ (range: $3.7-24.1$ ) in total height, and $38.7 \pm 1.8 \mathrm{~cm}$ dbh (range: 12.5 62.2). They averaged $17.3 \pm 2.2 \mathrm{~cm}$ larger in $\mathrm{dbh}$ than neighborhood trees. The 10 maternity roost trees averaged $43.7 \pm 3.5 \mathrm{~cm}$ dbh (range: 29.2 $62.2) ; 24.3 \pm 3.6 \mathrm{~cm}$ larger than neighborhood trees. The 29 solitary roost trees averaged $37.0 \pm 2.1 \mathrm{~cm}$ dbh (range: 12.4 - 54.6), that were $14.9 \pm 2.6 \mathrm{~cm}$ larger than neighborhood trees. Maternity roost trees were not significantly larger than solitary roost trees $(t=1.64, \underline{P}=0.12)$.

Bats found in maternity aggregations returned to the same roost tree for a mean of eight days (range: $1-21$ ). We tracked one bat from a tree containing a maternity aggregation of 55 bats to a second tree with a maternity aggregation of 44 bats about $440 \mathrm{~m}$ away. The following evening no bats were observed exiting from the first roost tree, although foraging conditions appeared favorable. It is not clear how many bats from the first roost tree moved to the second tree with the bat we were tracking.

We tracked solitary roosting bats to an average of three roost trees (range: $1-6$ ). On five occassions, solitary bats used the same tree on consecutive days. Although foraging conditions appeared favorable, we are not sure if the bats remained in their roosts overnight or if they left and returned to the same roost later that night. Three of the solitary roosting bats returned once or more to trees that they had used several days before. The mean distance a solitary roosting bat traveled between successive roost trees was $405 \pm 93.7 \mathrm{~m}(\underline{\mathrm{n}}=$ 13). All bats traveled a mean of $2064 \pm 443 \mathrm{~m} \mathrm{(n}=$ 12) from the point where they were captured and released to their first roost tree. This distance is significantly greater $(t=3.67, \underline{P}=0.0037)$ than the average distance solitary bats would travel between successive roost trees.

\section{DISCUSSION}

Roost microsites varied depending on whether they were used by maternity aggregations or solitary bats. Maternity aggregations were always 
found in some type of hollow cavity within a tree bole. Usually these were cavities created by woodpeckers, likely hairy woodpeckers Picoides villosus or black-backed woodpeckers $P$. arcticus, based on the $7.5-10-\mathrm{cm}$ diameter cavity openings (Terres 1980). Although considered rare in the Black Hills (Black Hills National Forest 1989), Lewis' woodpeckers Melanerpes lewis, northern flickers Colaptes auratus or three-tocd woodpeckers Picoides tridactylus might also have created some of the roost cavities. Solitary roosts were located under loose bark or in some type of natural crack or crevice in the tree bole. Only once did a solitary bat use a woodpecker cavity. Although silver-haired bats are cryptically colored, they were never observed roosting openly on a tree trunk, limb, or in foliage where they would have been directly exposed to the elements or predators. This behavior differs from that of the other cryptically colored tree-roosting bats (e.g. Lasiurus spp.), which tend to roost among tree foliage (Shump and Shump 1982a, , b). Roosts suitable for maternity aggregations may limit silverhaired bat abundance; clearly they are less available across the landscape than are solitary roosts. Reproductive females secm to require roosts that provide a relatively enclosed and unexposed space for protecting the young or maintaining the necessary thermal environment.

Solitary roosts occurred more frequently than expected on the south-facing sides of tree boles. Cavities used by maternity aggregations also tended to have openings facing south. We hypothesize that these roosts are warmer than if they faced north because of insolation. These hypothesized differences should result in energetic savings, providing more energy for growth and development (McNab 1982). Reller (1972) has shown that several species of woodpeckers orient their nest cavity openings southwesterly for warming by the sun or ventilation by the wind. It is unclear whether bat use of cavities with south-facing entrances reflects the selections of bats or of woodpeckers.

Silver-haired bats roosted exclusively in trees during the summer. Although all but one of the roosts were located in ponderosa pine trees, the dominance of ponderosa pine in our study area prevented us from testing for tree species selection. The wide geographic distribution of silver-haired bats relative to that of ponderosa pine, and the use by silver-haired bats of deciduous roost trees in Canada (Novakowski 1956, Parsons et al. 1986, Barclay et al. 1988), suggest that these bats select for the structure of the roost microsite rather than particular tree species. As for other tree-roosting bats
(Tidemann and Flavel 1987), it is unlikely that tree species is important to silver-haired bats except that at the local level one species may tend to have preferred attributes.

Roost trees were standing, dead, and larger than average in diameter. The one living tree selected as a roost was dying (stage 2), missing its top, and had several dead limbs and woodpecker holes high in the bole. Although the importance of snags as roost sites in other forest types remains in question, large snags appear to be important resources for silver-haired bats in ponderosa pine forests.

Undoubtedly, snags are important in providing roost sites for silver-haired bats. It was not surprising then that forest stands containing silver-haired bat roosts had snag densities of 21 snags/ha, a value much higher than current management objectives. These densities were even higher in a portion of the study area which contained a large number of fire killed trees. How fire supression has affected the number of snags in the Black Hills remains unclear. Early photographs suggest that many forested areas in the Black Hills were more open with many standing dead trees (Knight 1994).

\section{$\downarrow \quad$ CONCLUSIONS}

Snags are important in the roosting ecology of the silver-haired bat, and may affect the distribution and abundance of this species. As suitable roosts are critical resources for bat survival (Kunz 1982b), we hypothesize that logging practices that have reduced snag densities have caused silverhaired bat populations to decline over wide areas in the last 100 years. We advocate more intensive research on the habitat requirements of snagroosting bats, which are just beginning to be known. Because a large number of vertebrates use snags for nesting or roosting (Thomas et al. 1979), efforts to conserve roosts sites for silver-haired bats should provide habitat for a variety of species.

\section{ACKNOWLEDGEMENTS}

Support for this project was provided by the University of Wyoming-National Park Service Research Center; the National Park Service, Rocky 
Mountain Region; and the National Biological Survey, Midcontinent Ecological Research Center. We especially appreciate support from Kate Cannon and the staff of Jewel Cave National Monument, from Mike Bogan of the National Biological Survey, and from Jocl Tigner, Oscar Martinez, and Alice Lippacher of the Black Hills National Forest. Mike Bjelland and Jay Grant provided valuable field assistance.

\section{LITERATURE Cited}

Barbour, R. W. and W. H. DAVIS. 1969. Bats of America. Univ. of Kentucky, Lexington, Kentucky, 286 pp.

Barclay, R. M. R., P. A. Faure, and D. R. Farr. 1988. Roosting behavior and roost selection by migrating silver-haired bats Lasionycteris noctivagans. Journal of Mammalogy, 69:821-825.

Black Hills National Forest. 1989. Black Hills National Forest: checklist of birds. USDA Forest Service.

Knight, D.H. 1994. Mountains and Plains: The Ecology of Wyoming Landscapes. Yale University Press, New Haven and London, $338 \mathrm{pp}$.

Kunz, T. H. 1982a. Lasionycteris noctivagans. Mammalian Species 172. American Society of Mammalogists, New York, 5 pp.

Kunz, T.H. 1982b. Roosting ecology of bats. Pp. 155 In Ecology of Bats (T. H. Kunz, ed.). Plenum Press, New York, 425 pp.

MCNab, B. K. 1982. Evolutionary alternatives in the physiological ecology of bats. Pp. 151200 In Ecology of Bats (T. H. Kunz, ed.). Plenum Press, New York, 425 pp.

Novakowski, N. S. 1956. Additional records of bats in Saskatchewan. Canadian FieldNaturalist, 70:142.
Parsons, H. J., D. A. Smith, and R. F. Whittam. 1986. Maternity colonies of silver-haired bats, Lasionycteris noctivagans, in Ontario and Saskatchewan. Journal of Mammal., 67:598-600.

Perkins, J. M. and S. P. Cross. 1988. Differential use of some coniferous forest habitats by hoary and silver-haired bats in Oregon. Murrelet, 69:21-24.

Reller, A. W. 1972. Aspects of behavioral ecology of Red-headed and Red-bellied Woodpeckers. American Midland Nat., 88: 270290.

Shump, K. A. and A. U. Shump. 1980. Comparative insulation in Vespertilionid bats. Comparative Biochemistry and Physiology, 66A:351-354.

Shump, K. A. and A. U. Shump. 1982a. Lasiurus borealis. Mammalian Species 183. American Society of Mammalogists, New York, 6 pp

Shump, K. A. and A. U. Shump. 1982b. Lasiurus cinereus. Mammalian Species 185. Amcrican Socicty of Mammalogists, New York, $5 \mathrm{pp}$.

Terres, J. K. 1980. The Audubon Society: encyclopedia of North American birds. Wings Books, Avenel, New Jersey, 1109 pp.

Thomas, D. W. 1988. The distribution of bats in different ages of Douglas-fir forests. Journal of Wildlife Management, 52:619. 626.

Thomas, J. W., R. G. Anderson, C. Maser, and E. L. Bull. 1979. Snags. Pp. 60-77 In Wildlife Habitats in Managed Forests: the Blue Mountains of Oregon and Washington ( $\mathrm{J}$. W. Thomas, ed.). USDA Forest Service, Agricultural Handbook no. 553.

Tidemann, C. R., and S. C. Flavel. 1987. Factors affecting the choice of diurnal roost site by tree-hole bats Microchiroptera in southeastern Australia. Australian Wildlife Research, 14:459-473. 